$$
\text { ノート }
$$

脳血管撮影に対する片面増感紙・両面乳剂フィルムシステムの適用

宇部興産株式会社中無病院放射線科

$$
\begin{aligned}
& \text { 隅田博臣・久米祐司・瀬畑修二 } \\
& \text { 大野忠正・桜究爾 } \\
& \text { 山口大学医学部附属病院放射線部 } \\
& \text { 大塚昭義・山内秀一 } \\
& \text { 上田克彦・迎英紀 } \\
& \text { (論文受理 } 1985 \text { 年 } 8 \text { 月22日) } \\
& \text { （最終論文受理１986年 } 9 \text { 月19日） }
\end{aligned}
$$

Key words: Screen-film system, Parallax effect, Single screen system, Image quality, Cerebral angiography

\title{
CLINICAL APPLICATION OF ULTRA HIGH-SPEED, SINGLE-SCREEN /DOUBLE-EMULSION FILM IN CEREBRAL ANGIOGRAPHY
}

\author{
Hiroomi Sumida, Yuji Kume, Shuji Sebata, \\ Tadamasa OHno and Kanji Sakura \\ Department of Radiology, Ubekohsan Central Hospital.

$$
\begin{gathered}
\text { Akiyoshi Ohtsuka, Shuichi Yamauchi, } \\
\text { Katsuhiko Ueda and Hideki Mukae }
\end{gathered}
$$ \\ Department of Radiology, Yamaguchi University Hospital.
}

(Article received; Aug., 22, 1985)

\section{Summary}

In the A.P radiograph of cerebral angiography, the incident angles of the X-ray beam to image receptor are from 20 to 40 degrees.

Therefore, a lock of sharpness caused by the parallax effect is disadvantageous for the double-screen/ double-emulsion film system (Double system).

We have combined double-emulsion film with ultra high-speed rare-earth single-screen for the purpose reducing the parallax effect and measured its basic imaging properties, and studied the clinical applications. 
As a result, the ultra high-speed rare-earth single-screen/double-emulsion film system (Single screen system) was found to be better than the double system regarding sensitivity and MTF, and also good results were obtained in the clinical examinations.

\section{1.はじめに}

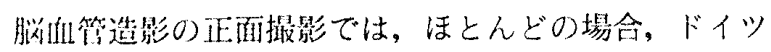
水平面に対してX線錐を15度ないし30度斜入させる。さ らに嚚床では，ドイツ水平解が受光系（增感紙・フィル ムシステム）に対して重直にならないことも多く，椎骨 動脈做影（VAG）では，X線錐の入射传度が受光系に対 して45度にもなることがある。Cアームやフィルムチェ ンジャの倾斜機橉を用いると，X線錐と受光系が学に垂 㨁となるため，斜入によるボケは䦌題とならない。しか

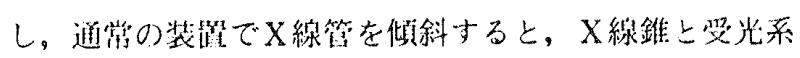
(チェンジャ)とは垂直にならず，斜人によるボダが大き な陵觜となる゙。

斜入効果の低減には, 片面增感紙と片面乳剂フィルム の組合せが最適である2)。しかし，感度の低下とフィルム が高価である点から現実的とはいえない。そこで，われ われは十分なシステム感度を有し，斜入效果を低減させ ることを目的として，片面の超高感度希土類堷感紙の試

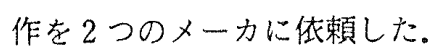

試作片面増感紙に画面乳剂フィルムを組合せて片面増 感紙システムを構成した。このシステムの基本的な特性 を測定し，通常の両面システムのデータと比較した。ま たここれを臨床へ適用し，通常のシステムによる写真と 比較検討した。

\section{2. 方法}

\section{1 使用機器}

通常システム

増感紙: KRUPPA（シーメンス）

フィルム:XRP（コダック）

片面增感紙システム

増感紙：試作片面増感紙

$$
\begin{gathered}
\text { 〔KU: 小西六〕[G12:フジ } \\
\text { フィルム: } \mathrm{AO} \text { (小西六), RX-OH (フジ) }
\end{gathered}
$$

濃度計：PDA-11 (小西六)

ミクロフォトメータ：PDS-15改良型(小西六)

スリット：幅 $10 \mu \mathrm{m}$, 高さ $2.0 \mathrm{~mm}$ (東芝)

X線発生装置：HD150G-12 (竄津)

フィルムチェンジャ：PUCK 傾斜機棈なし(シーメン ス)

\section{2 画像特性}

試作した超高感度增感紙（片面）と通常の増感紙（両 面）を用い，X線の斜入によるボケ効果をMTFによっ て比較しだ)。

Fig.1に示すようにスリットとX線管の中心を合わ せ，受光系を 0 度から50度傾けてスリット像を撮影した。 スリットと受光系の距䨆は，斜入解度が50度のときに最 も近つけた距離に固定し，各争度で抾大率が一定になる ようにした。桩大率は1.05倍以下であり、スリット幅 $(10$ 。 $\mu \mathrm{m})$ を教虑して，拡大による補正を行わなかった。

また，両システムの感度比は，特性曲線から求めた。

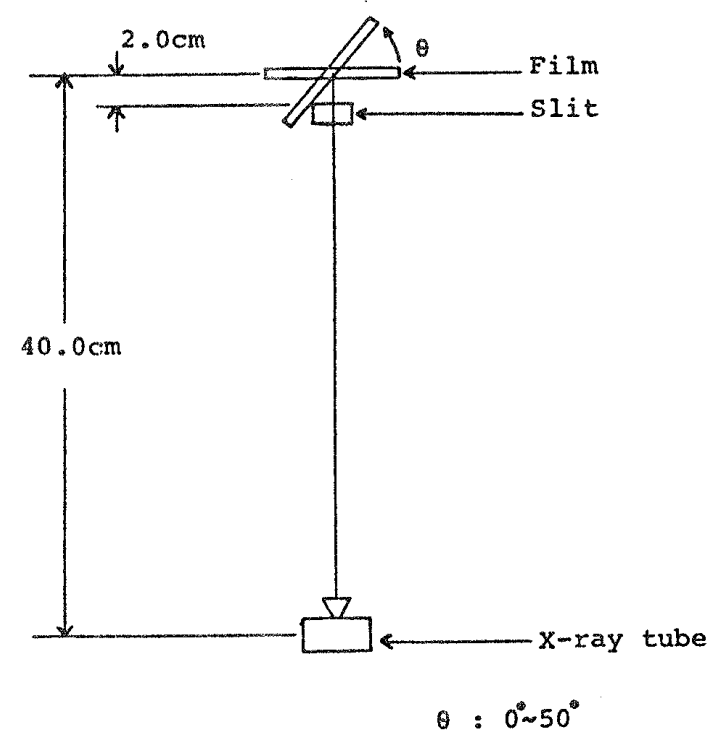

Fig. 1 Schematic diagram of MTF measured by using a slit.

\section{3.結果}

Fig.2にX線を垂㨁入射したときの MTFを示すが， 両システムともあまり変らない。

Fig.3は通常システムで, X線錐を0度から50度まで 変えたときのMTFである。10度では０度とあまり差が ないが，20度以上になるとMTFは急激に低下する。角 度が40度になると，㤎間周波数が2.0サイクル附近で，ま た，50度になると，1.5サイクルでレスポンスは 0 とな る。

片面增感紙システムの0度と50度のMTFを Fig.4 


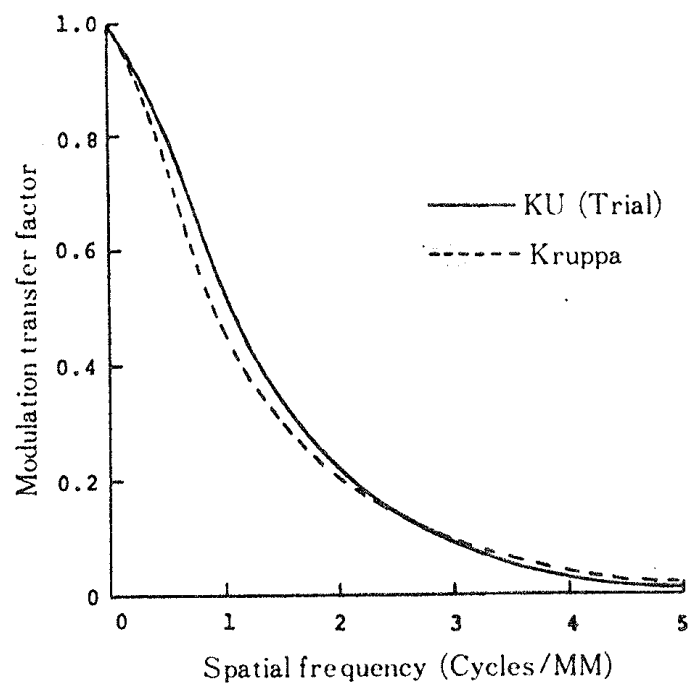

Fig. 2 MTFs of KU(back: trial screen)-AO (solid curve) and KRUPPA-XRP (dot. ted curve) systems.

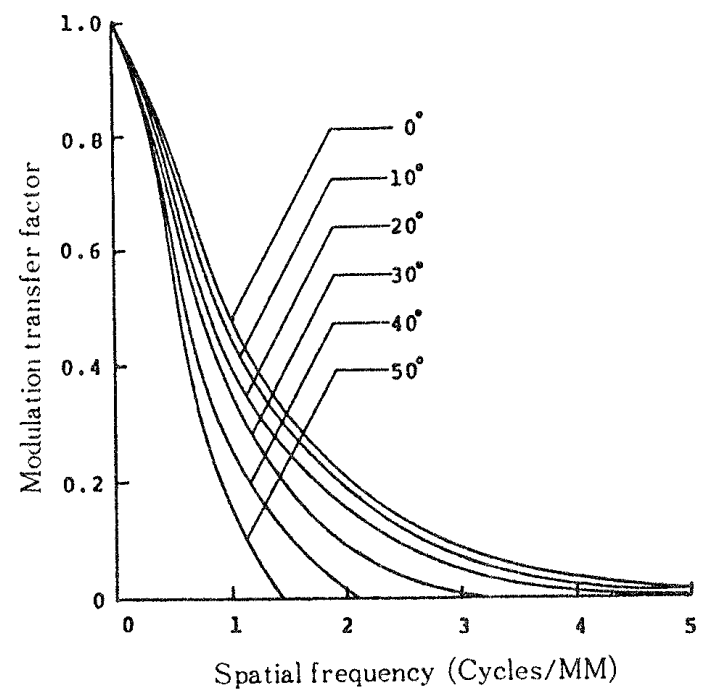

Fig. 3 MTFs of KRUPPA-XRP system. Incident angles are from 0 to 50 degrees.

に示すが，阿面増感紙と違って角度による差が少ない。 闹図に両システムの比較を示すが，片面増感紙システム では，X線錐を50度斜入させても通常システムの 30 度よ りMTFが上舁していることがわかる。

両システムの特性曲線を Fig. 5 に示す。これから両シ ステムの感度を比較すると, $\mathrm{KU}$ (片面)・AOは。 KRUPPA・XRPに対して約 2 倍の感度を有している。 グラジェントは通常のシステムの方が少し高い。

\section{4. 臨床への応用}

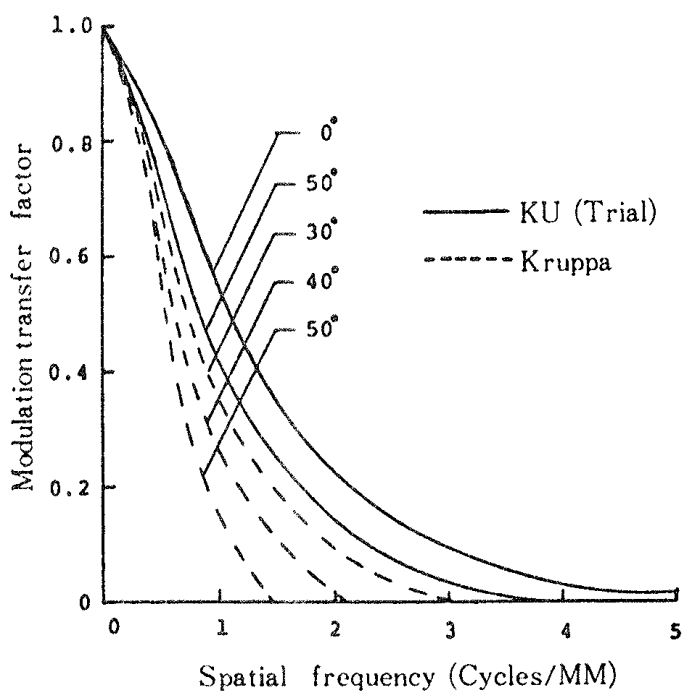

Fig. 4 Comparison of MTFs of KU (back : trial screen)-AO (solid curves) and KRUPPA.XRP (dotted curves) systems.

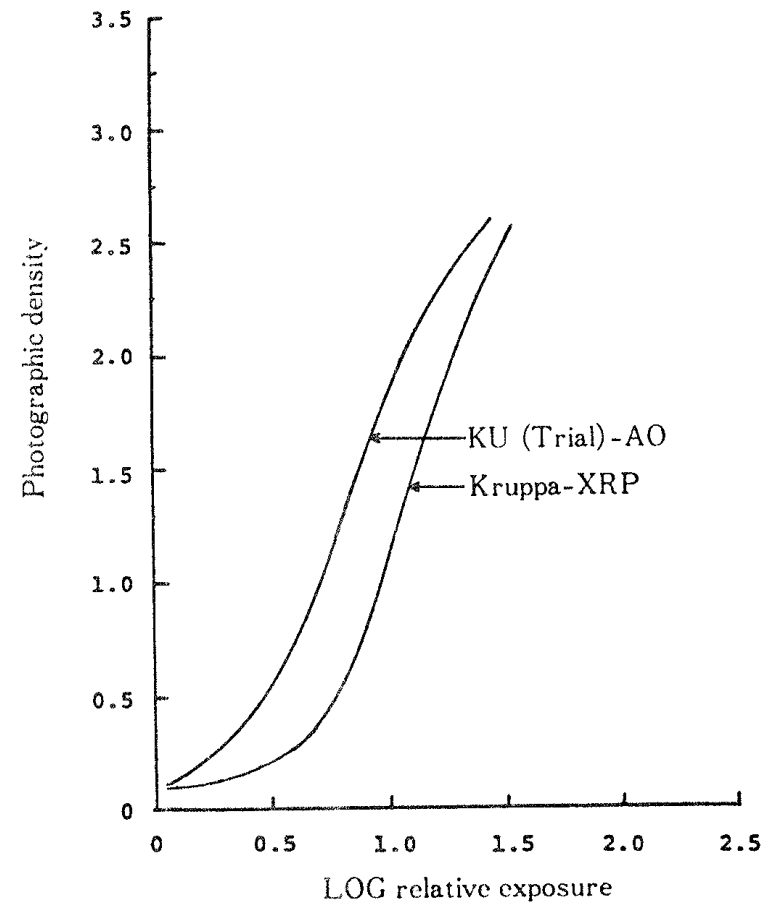

Fig. 5 Comparison of characteristic curves of KU(back : trial screen)-AO and KRUPPA-XRP systems.

\section{1 フィルムチェンジャ (PUCK) の改良}

前述の基本特性から，X線の斜入に対して雨面システ ムより片湎增感紙システムの方が明らかに有利であるこ とが判明した。このシステムを臨床に沁用するため，フ イルムチェンジャに少し乎を加えた。

まず，楛作した片面增感悢をチェンジャのback 側に 


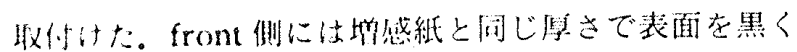

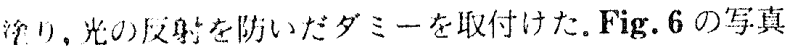
に心⿺。

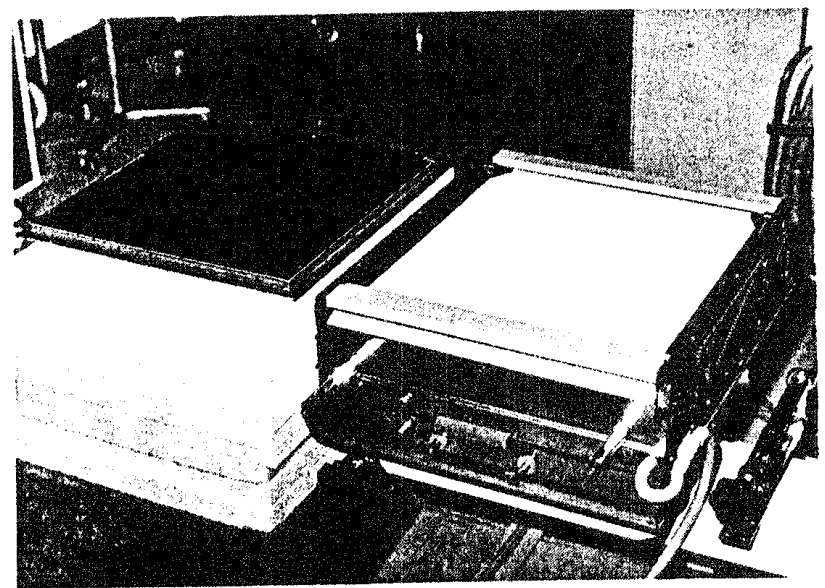

Fig. 6 Photograph of PUCK with the single screen system. Front screen of black dummy (left) and back screen of ultra high-speed rare-earth (right).

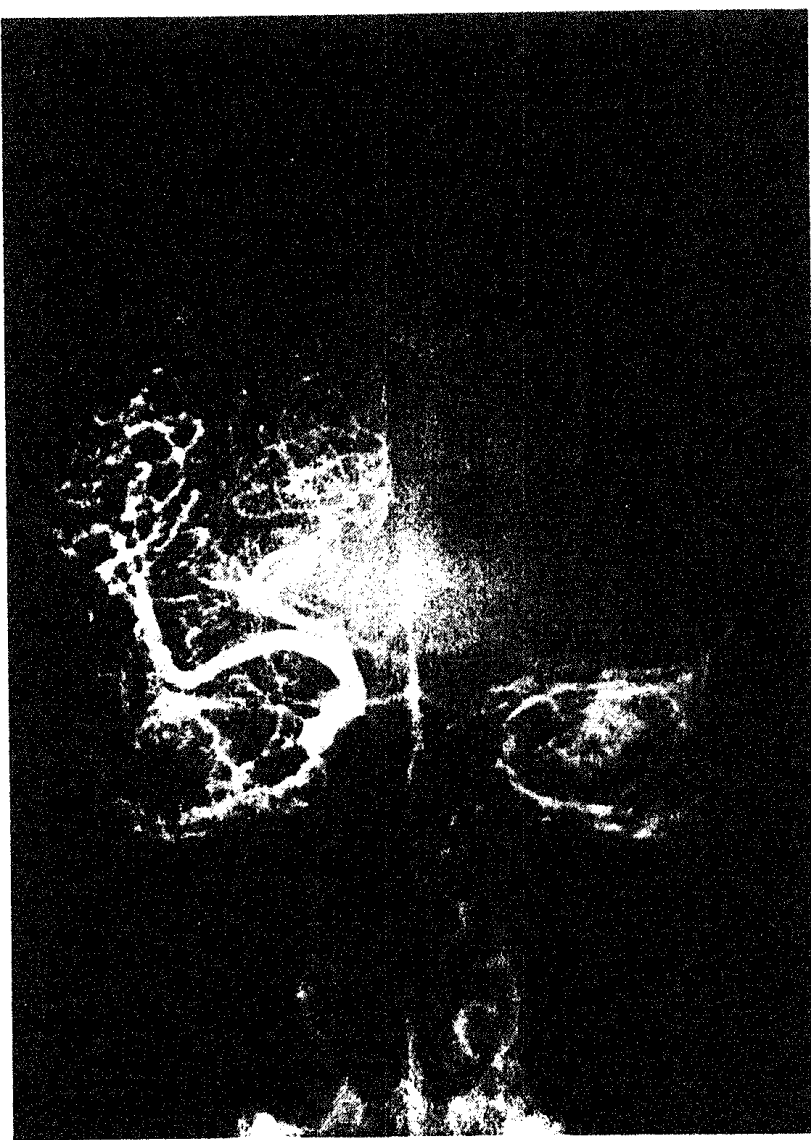

Fig. 7 Carotid artery angiogram with the double-screen/double-emulsion film sys tem. Incident angle is 10 degrees. (78 $\mathrm{kV}, 300 \mathrm{~mA}, 0.063 \mathrm{sec}, \mathrm{FFD} 110 \mathrm{~cm}$ )
片面增感紙システムの密着性を，金絧とチャート法て 確認した。その結果，密普性には闍題なく，搬送性につ いても，十分PUCKの動作に適応できた。

\section{2 踽床写真}

次に，前記のチェンジャを使って撮影した症例写真を 示す。

Fig.7は通常システムによる頸動脈撮影（以下 $\mathrm{CAG}$ とする）の写真である。顎を引かせているため，X線錐 の入射角度は10度である。基本特性でもわかるように， 10度ではあまりMTFが低下しないため，臨床写真でも 血管走行は鮮明である。

Fig.8に通常システムによる椎骨動脈撮影（以下 VAGとする)の写真を示す。X線錐の入射角度は30度で あるが，横方向に走る後大脳動脈や上小脳動脈が不鮮明 である。

Fig.9は片面増感紙システムを用いたCAGの写真で ある。斜入解度は20度であるが Fig. 7 の通常システムの 写真と比べて遜色があるとは思えない。

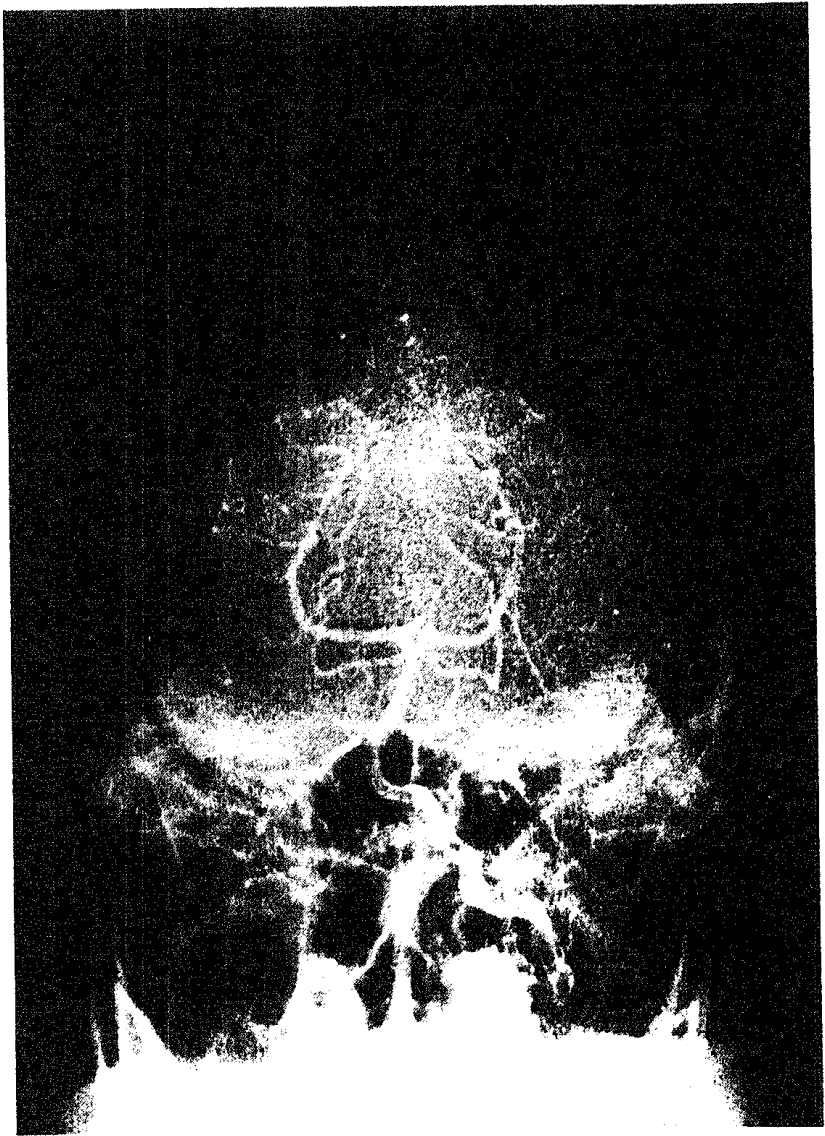

Fig. 8 Vertebral artery angiogram with the double-screen/double-emulsion film system. Incident angle is 30 degrees. (85 $\mathrm{kV}, 300 \mathrm{~mA}, 0.08 \mathrm{sec}, \mathrm{FFD} 110 \mathrm{~cm})$ 


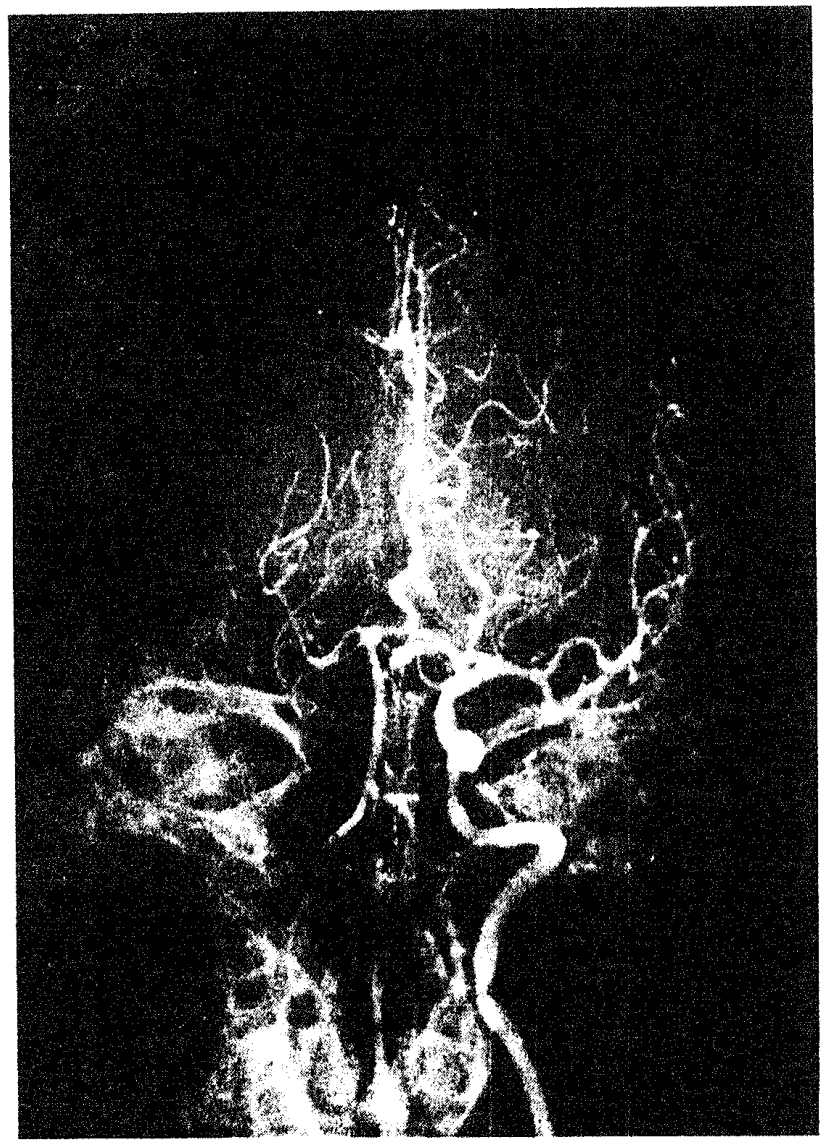

Fig. 9 Carotid artery angiogram with the single-screen/double-emulsion film sys. tem. Incident angle is 20 degrees. (75 $\mathrm{kV}, 300 \mathrm{~mA}, 0.04 \mathrm{sec}, \mathrm{FFD} 110 \mathrm{~cm}$ )

片面堌感紙シスデムを用いたVAGの写真をFig.10 沪示す，斜入角度は45度であるが，後大脳動脈や上小脳 動脈の走行をはっきり追うことができる。

Fig. 11 は片面増感紙システムによるVAG 斜位の 2 倍拡大写真である。通常システムより感度が約 2 倍に上 昇したので，入射角度が45度でも抬大連続撮影が可能と なった症例である。

\section{5. 考 察}

X線を斜入したときの MTF特性は，今までにも報告 シれているように，片面增感紙・片面乳剂フィルム（片 面）システムが通常の両面システムよりかなり显れてい ろ2)。今回の片面壃感紙に両面乳剂フィルムを組合せた 和面増感紙システムも，予想通り片面システムの利点を 份していた。このことは，臨床写真でも十分確認できた。 試作した 2 種類の片面堌感紙の感度は組合せるフィル ムによって多少異なるが, LFII (FS) - RX(A)の 5〜 7 街である、X線装㤠にもよるが，血管連続撮影では，受

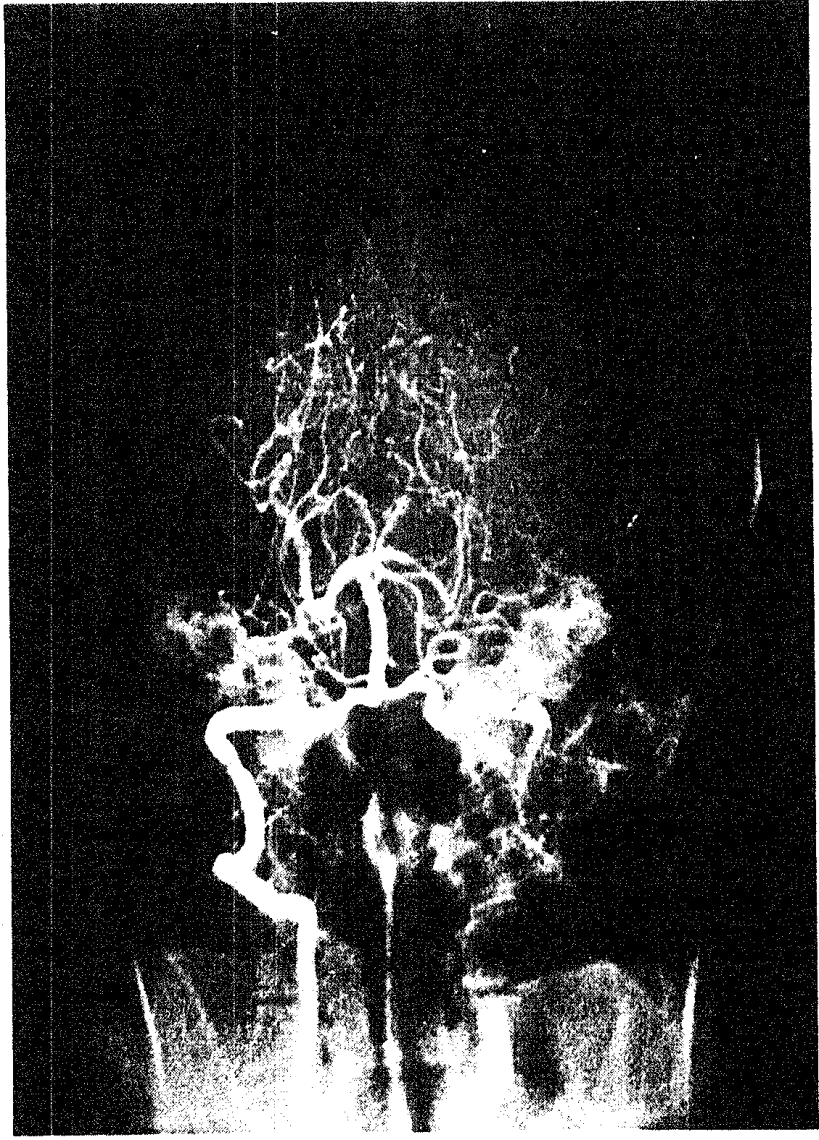

Fig. 10 Vertebral artery angiogram with the single-screen/double-emulsion film sys tem. Incident angle is 45 degrees. (78 $\mathrm{kV}, 300 \mathrm{~mA}, 0.05 \mathrm{sec}, \mathrm{FFD} 110 \mathrm{~cm}$ )

光系の感度がこの程度あれば，実用上困ることはないと 考える。この試作增感紙は後に，KU(小西六)，G12(フ ジ)として発表された。

前述したように，試作の片面増感紙システムは，通常 使用していたシステムより2 倍以上感度が上昇した。そ のため，X線管の負荷も小さくなり，通常のシステムで 纹不可能であった拡大連統撮影も可能となった。この結 果，読影が容易になり，診断精度も问上した。

現在一般に使用されている $\mathrm{G} 8$ (雨面)一RXOH システ

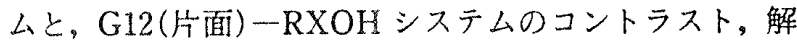
像力，感度を䒠際の写真で比較した。散乱体として $10 \mathrm{~cm}$ の水ファントムを用い，コントラストチャートを樑さ 5 $\mathrm{cm}$ に入れ，30度斜入して攝影した。雨システムを比ぺる と、コントラストはあまり変らないが，解像力は G12(片

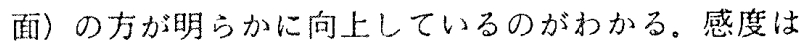
G8 (雨面) の方が $\mathrm{G} 12$ （片喕）上り少し高いが，その差 泣小さく，管電匡にして $3 \mathrm{kV}$ 程度の美であった。

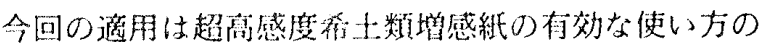




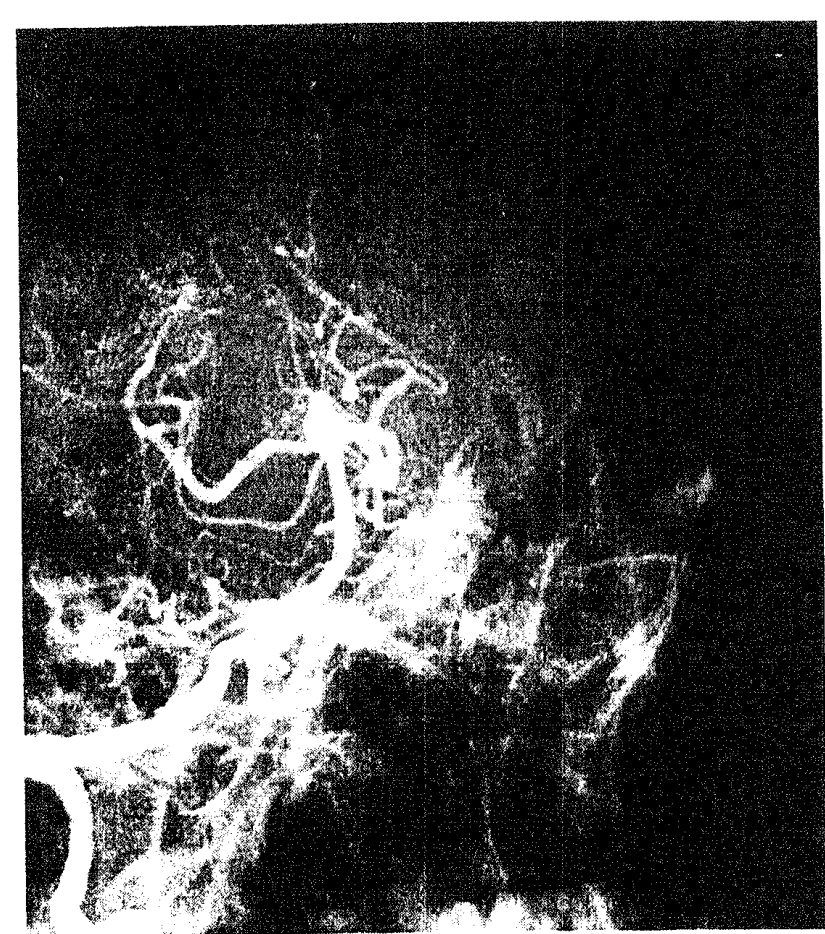

Fig. $112 \mathrm{X}$-vertebral artery angiogram with the single-screen/double-emulsion film system. Incident angle is 45 degrees. (105 $\mathrm{kV}, 30 \mathrm{~mA}, 0.16 \mathrm{sec}, \mathrm{FFD} 100 \mathrm{~cm}$ )
○一正える。

\section{6. 結 論}

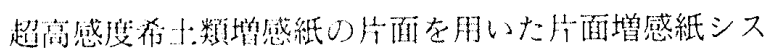

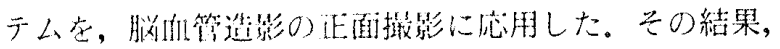

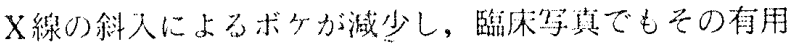
性を磪愳できた。また。システム感度も通常システムよ

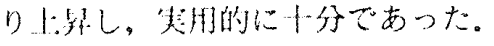

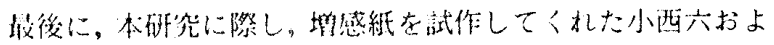

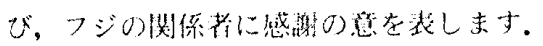

\section{文献}

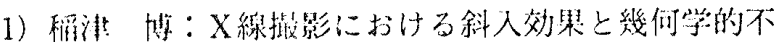

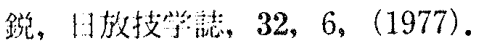

2) Yoshiharu Higashida, Paul H Frank MD, Kunio Doi, Ph. D., et al.: High-Speed, Single-Screen/ Single-Emulsion Film Systems: Basic Imaging Properties and Preliminary Clinical Applications. Radiology 149, 571-577, (1983).

3) Marcia $E$ Dahle. Arthur G Haus: Factors affectin the experimental line spread function (LSF) measurement and modulation transfer function (MTF) calculation including deviation in characteristic curve shape. Application of Opucal Instrumentation in Medicine V, 233, (1980). 